\title{
STABILITY OF CHITOSAN-TRIPOLYPHOSPHATE COMPLEX- ENCAPSULATED ANTHOCYANIN AT HIGH WATER ACTIVITY
}

\author{
[Stabilitas Antosianin yang Terenkapsulasi melalui Komplek Kitosan-Tripolifosfat \\ pada Kondisi Aktivitas Air yang Tinggi]
}

\author{
Umi Laila ${ }^{1) \star}$, Rochmadi $^{2)}$, Sri Pudjiraharti ${ }^{3)}$, Rifa Nurhayati ${ }^{1)}$, Ervika Rahayu Novita Herawati ${ }^{1)}$, \\ Dini Ariani ${ }^{1}$, and Yuniar Khasanah ${ }^{1)}$

\footnotetext{
1) Research Division for Natural Product Technology, Indonesian Institute of Sciences, Yogyakarta

2) Department of Chemical Engineering, Faculty of Engineering, Gadjah Mada University, Yogyakarta
} \\ 3) Development Unit for Clean Technology, Indonesian Institute of Sciences, Bandung
}

Received May $20^{\text {th }} 2020 /$ Accepted December $24^{\text {th }} 2020$

\begin{abstract}
Previous study successfully conducted encapsulation of the purple-fleshed sweet potato's anthocyanin but the study has yet to reveal the stability of encapsulated anthocyanin. Therefore, this research aims to observe the stability of encapsulated anthocyanin regarding the characteristic of low anthocyanin stability, which depends on environmental factors, such as temperature, $\mathrm{pH}$, humidity, and water activity. The kinetic parameters of stability, including kinetic constant $(\mathrm{k})$, reaction order, and half-life $\left(t_{1 / 2}\right)$, were also studied. Stability testing was conducted in high water activity of 0.75 and various incubation temperatures at $16,25,35$, and $45^{\circ} \mathrm{C}$. Un-encapsulated anthocyanin extract was also tested for its stability in the same condition in order to be compared with encapsulated anthocyanin. This study revealed that the encapsulated anthocyanin had lower stability than un-encapsulated anthocyanin extract. It was proven by higher kinetic constant and lower half-life of encapsulated anthocyanin for every incubation temperature which was induced by higher $\mathrm{pH}$ of encapsulated anthocyanin compared with anthocyanin extract. Besides, high water activity reduced glass transition temperature $(\mathrm{Tg})$, in which encapsulated anthocyanin was in rubbery state. Both encapsulated anthocyanin and anthocyanin extract were degraded following the first order kinetic. Using the Arrhenius equation, it was obtained that the degradation kinetic constant of encapsulated anthocyanin was stated as $k=420.44 \exp (-23.33 / R T)$. Meanwhile, $k=1.12 \times 10^{6}$ $\exp (-46.70 / R T)$ described degradation of kinetic constant of anthocyanin extract. The stability test revealed that the application of encapsulated anthocyanin was not suitable for wet-type food product.
\end{abstract}

Keywords: anthocyanin, chitosan, encapsulation, stability, tripolyphosphate

\begin{abstract}
ABSTRAK
Penelitian mengenai enkapsulasi antosianin ubi jalar ungu telah berhasil dilakukan, tetapi penelitian tersebut belum mengungkap stabilitas antosianin terenkapsulasi. Oleh karena itu, penelitian ini bertujuan untuk mempelajari stabilitas antosianin terenkapsulasi berkaitan dengan karakteristik stabilitas antosianin yang rendah yaitu tergantung pada faktor-faktor lingkungan, seperti suhu, $\mathrm{pH}$, kelembapan, dan aktivitas air. Parameter kinetika stabilitas yang mencakup konstanta kinetika (k), orde reaksi, waktu paruh ( $\left.t_{1 / 2}\right)$ juga perlu dipelajari. Pengujian stabilitas dilakukan pada aktivitas air yang tinggi sebesar 0,75 dan suhu inkubasi yang divariasikan pada 16, 25, 35, dan $45^{\circ} \mathrm{C}$. Ekstrak antosianin yang tidak dienkapulasi juga diuji stabilitasnya pada kondisi yang sama, dengan tujuan untuk dibandingkan stabilitasnya terhadap antosianin terenkapsulasi. Uji stabilitas menunjukkan bahwa antosianin terenkapsulasi memiliki stabilitas yang lebih rendah daripada antosianin yang tidak terenkapsulasi. Hal tersebut terbukti dengan konstanta kinetika yang lebih tinggi dan waktu paruh yang lebih rendah pada antosianin terenkapsulasi untuk masing-masing suhu inkubasi. Hasil tersebut dikarenakan faktor $\mathrm{pH}$ antosianin terenkapsulasi yang lebih tinggi daripada $\mathrm{pH}$ ekstrak antosianin. Selain itu, aktivitas air yang tinggi menurunkan suhu gelas transisi $(\mathrm{Tg})$, dengan antosianin terenkapsulasi berada pada kondisi bentuk karet (rubbery). Antosianin terenkapsulasi dan ekstrak antosianin mengalami degradasi menurut kinetika orde 1. Melalui persamaan Arrhenius, didapatkan bahwa konstanta kinetika degradasi antosianin terenkapsulasi dinyatakan sebagai $k=420,44 \exp (-23,33 / R T)$. Sementara itu, $k=1,12 \times 10^{6}$ exp $(-46,70 / R T)$ menggambarkan konstanta kinetika degradasi ekstrak antosianin. Berdasarkan uji stabilitas, antosianin terenkapsulasi tidak layak untuk diaplikasikan pada produk pangan bertipe basah.
\end{abstract}

Kata kunci: antosianin, enkapsulasi, kitosan, stabilitas, tripolifosfat

\footnotetext{
The manuscript has been presented in The $16^{\text {th }}$ Asean Food Conference 2019, October $15^{\text {th }}-18^{\text {th }} 2019$, Bali-Indonesia
}

${ }^{*}$ Corresponding Author: E-mail: umilaila38@gmail.com 


\section{INTRODUCTION}

Anthocyanins giving rise to various natural pigment or color from red, blue, and violet to plant parts, such as leaf, root, fruit, and tuber, are secondary metabolites dominantly produced by plants (Diniyah et al., 2010). They belong to flavonoid compounds with a chemical structure composed of two aromatic ring connected to each other by oxygen-attached heterocyclic ring. One of the aromatic ring is bonded to sugar group through glycosidic bond (Bueno et al., 2012). Just like other flavonoid compounds, anthocyanins are known to have beneficial bioactivities and functionalities. Compared with other antioxidants, such as (+)catechin, vitamin E, BHA (butylated hydroxyanisole) and BHT (butylated hydroxytoluene), anthocyanins have higher antioxidant capacity (Justino, 2017). Anthocyanins play key roles in antidiabetic and antiinflammatory activities, improve visions (Khoo et al., 2017), and maintain cardiovascular activity (Whitson, 2010) and heparin system (Hou et al., 2013).

The superiority of anthocyanin's bioactivities are opposed to their stability, since anthocyanins are very sensitive to environmental factors, i.e. $\mathrm{pH}$, temperature, light, oxygen, water activity, and others. In particular, anthocyanins are different from other flavonoid in terms of their $\mathrm{pH}$ change since their structure undergoes different conformations. The conformations are flavylium cation, quinoidal base, carbinol base, and chalcone that arise in $\mathrm{pH} 1$ 3, 3-4, and 5, 6 respectively (Faria et al., 2013). Anthocyanin stability will increase along with the decreasing $\mathrm{pH}$ so that flavylium cation conformation can achieve the highest stability. The high stability is achieved by the conformation capability to avoid hydrolysis reaction of glycosidic bond (Turumtay et al., 2015). Meanwhile, the increasing temperature plays an important role in influencing anthocyanins' stability by shifting the conformation to carbinol and chalcone. Alteration of conformation is induced by hydrolysis of glycosidic bond by which more opened and unstable anthocyanin structures, namely carbinol and chalcone, are formed (Sun et al., 2011). The decrease in anthocyanin stability by oxygen is resulted from either direct oxidation or oxidator enzyme aid (Patras et al., 2010). The oxidation results in brown-coloured or colorless substance (Martynenko and Chen, 2016). The lowering of anthocyanin stability can also be induced by the presence of light (Askar et al., 2015).

Several studies mentioned that encapsulation is the way to reduce sensitivity of anthocyanin toward environmental factors that lower anthocyanin stability (Parisi et al., 2014) to allow the encapsulation to improve anthocyanin stability (Kanokpanont et al.,
2018). Our previous study reported that anthocyanin was successfully encapsulated by chitosan-sodium tripolyphosphate complex using emulsificationcrosslinking technique (Laila et al., 2019). The research studied and optimized parameters influencing encapsulation in which the best microcapsule was obtained by the stirring intensity of $1600 \mathrm{rpm}$, chitosan concentration of $3 \%(\mathrm{w} / \mathrm{v}), \mathrm{pH}$ of chitosan, NaTPP solution of 3.0, and ratio of core to chitosan concentration of $150 \%(\mathrm{w} / \mathrm{w})$. The optimization was focused to parameters, i.e. efficiency of encapsulation, particle size distribution, and antioxidant activity. The use of NaTPP as crosslinker was considered by its availability in food application due to low toxicity and immediate gel formation.

It had been mentioned that dry products, including microcapsule tend to have slow chemical changes. However, some conditions, like storage at temperature above their glass-transition temperature $(\mathrm{Tg})$ will accelerate deteriorative process (Slade and Levine, 1991). It is known that glass-transition temperature $(\mathrm{Tg})$ will be affected by water activity. Alpizar-Reyes et al. (2017) said that increasing water activity will reduce $\mathrm{Tg}$ because water plays the role as plasticizer which will reduce viscosity and increase free volume, so that active (solid) molecule can move intensely. In other words, it will enlarge molecule structure to change from glassy state towards rubbery state. In this regard and given the possibility or impossibility to apply encapsulated anthocyanin in high humidity or wet-type food product like yogurt, pasta, or drink, the present study focused on observing stability of the encapsulated anthocyanin at critical condition, namely the condition with water activity of 0.75 and various incubation temperature at $16,25,35$, and $45^{\circ} \mathrm{C}$. The kinetic parameters of stability including kinetic constant reaction order, and half-life were also needed to study. Furthermore, Arrhenius equation was used to determine kinetic constant as the function of temperature. As a comparison, un-encapsulated anthocyanin extract was also tested for its stability using the same condition.

\section{MATERIALS AND METHODS}

\section{Materials}

The study used Chitosan of medical grade (PT. Biotech Surindo) with deacetylation degree of $>85 \%$ and viscosity of $130 \mathrm{cps}$, and sodium tripolyphosphate (NaTPP) with technical grade of $85 \%$ (SigmaAldrich, US). Purple-fleshed sweet potatoes (Ipomoe batatas L.) were supplied from Ngawi, East Java and obtained from Pasar Telo, Karangkajen Yogyakarta. 
Preparation of encapsulated anthocyanin (Laila et al., 2019)

Encapsulated anthocyanin was prepared according to our previous study (Laila et al., 2019). Preparation was initiated by anthocyanin extraction from purple fleshed sweet potatoes. Extraction was conducted using 3\% (w/v) citric acid (PT. Bratachem, Indonesia) in ethanol 96\% (CV. General Labora, Indonesia) as solvent. Purple fleshed sweet potatoes were extracted in chips with the ratio to solvent of $1: 1(\mathrm{w} / \mathrm{v})$. Extraction was done by maceration at the temperature of $35^{\circ} \mathrm{C}$, extraction time of 4 hours and with no light (dark) condition. Afterward, the extract was separated from solid residue using double filter cloth and the filtration was accomplished using Buchner funnel-vacuum filtration apparatus. The filtrate was concentrated in rotary evaporator (BUCHI R-114, Switzerland) at temperature of $50^{\circ} \mathrm{C}$ to obtain final concentrated anthocyanin extract with concentration of $70-80^{\circ}$ Brix.

Preparation of encapsulated anthocyanin was done using emulsification-crosslinking technique by applying paraffin liquid (CV. Alfa Kimia, Indonesia) as continuous phase and anthocyanin-chitosan liquid as dispersed phase (aqueous phase). Initially, anthocyanin extract was dissolved and homogenized in chitosan solution $3 \%(\mathrm{w} / \mathrm{v})$ using hot plate stirrer (Thermolyne Cimarec 2, USA). The chitosan solution was previously made by dissolving chitosan in $0.2 \mathrm{M}$ acetate buffer solution with $\mathrm{pH}$ of 3.0. Anthocyanin extract was added and mixed to chitosan solution in a concentration of $150 \%(\mathrm{w} / \mathrm{w})$ at a room temperature $\left(28-30^{\circ} \mathrm{C}\right)$ and the mixed solution was further named as aqueous solution (aqueous phase). Aqueous phase was dropped gradually using drop pipette to continuous phase with volume ratio of aqueous phase to continuous phase of $10 \%$. Previously, continuous phase was prepared by mixing sorbitan monooleate (SigmaAldrich, US) and paraffin liquid with a concentration of $2 \%(\mathrm{w} / \mathrm{v})$. While aqueous phase was dropped, stirring was carried out using mechanical agitation with flat 2-blade impeller in liquid system at stirring intensity of $1600 \mathrm{rpm}$ for getting water in oil (W/O) emulsion. Stable emulsion was obtained after emulsification was conducted for 1 hour. Furthermore, solidification of emulsion droplet was done by dropping $7.5 \%(\mathrm{w} / \mathrm{v})$ of sodium tripolyphosphate (NaTPP) aqueous solution to emulsion system. The stirring intensity was maintained at $400 \mathrm{rpm}$ during solidification. Solidification process was conducted for 4 hours until stronger encapsulated anthocyanin was gained. Stronger encapsulated anthocyanin was filtered and then washed using N-hexane (CV. General Labora, Indonesia) to eliminate paraffin (oil) residue by Buchner funnel-vacuum filtration apparatus. Encapsulated anthocyanin was further rinsed by ethanol, dried, and stored in vacuum desiccator at ambient temperature for 24 hours under dark condition before stability testing was conducted.

\section{Stability test (Jie et al., 2013)}

Stability test was aimed to investigate anthocyanin degradation during storage with a parameter to interpret the anthocyanin degradation of total anthocyanin content. Stability test was conducted under dark condition with water activity of 0.75 . The water activity of 0.75 was obtained by putting saturated $\mathrm{NaCl}$ (RAFINA, Indonesia) solution in closed container or desiccator. Equilibrium water activity was obtained by letting the condition for one week. After equilibrium was achieved, samples was put in the desiccator, exactly above $\mathrm{NaCl}$ solution without having a direct contact to the solution. In short, 100 $\mathrm{mg}$ of encapsulated anthocyanin was packed in polyethylene-based wrapping plastic, and it was laid in desiccator providing the equilibrium water activity of 0.75 . Desiccators were incubated at temperature of $16,25,35$, and $45^{\circ} \mathrm{C}$. The stability test was conducted for 35 days followed by regular sampling for further analysis of the total anthocyanin content. As a control and comparison, the same experiment and procedure was applied to anthocyanin extract with the concentration of $83^{\circ} \mathrm{Brix}$ and the $\mathrm{pH}$ of 2.21 .

\section{Analysis of total anthocyanins content (Giusti and Wrolstad, 2001)}

Determination of total anthocyanins content (TAC) in encapsulated anthocyanin and anthocyanin extract was conducted according to $\mathrm{pH}$-differential method (Giusti and Wrolstad, 2001). Analysis of TAC in encapsulated anthocyanin was initiated by anthocyanin extraction. Approximately, $100 \mathrm{mg}$ of encapsulated anthocyanin was mixed by $3 \mathrm{~mL}$ of $\mathrm{HCl} 2 \mathrm{M}$ (Merck Millipore, US)-ethanol (Merck Millipore, US) of $70 \%$ solvent with $\mathrm{HCl}$ to ethanol volume ratio of $2 / 3$. Extraction was conducted at temperature of $4^{\circ} \mathrm{C}$ under dark condition for 12 hours. Afterwards, centrifugation was conducted to separate extract liquid from encapsulant at $5000 \mathrm{rpm}$ for 10 minutes at room temperature using benchtop centrifuge (Centrifuge GEMMY PLC-05, Taiwan). Sample extract was added within extract to buffer volume ratio of $1 / 6$ into two kind of buffer, which are potassium chloride buffer of $0.025 \mathrm{M}$ (Merck Millipore, US) with a $\mathrm{pH}$ of 1.0, and sodium acetate buffer of $0.4 \mathrm{M}$ (Merck Millipore, US) with a $\mathrm{pH}$ of 4.5. Furthermore, the liquid was incubated under dark condition for 30 minutes. The absorbance of mixture liquid was measured by UV-Vis Spectrophotometer (Dynamica HALO RB-10 Spectrophotometer, UK) at wavelengths number of 530 and 700 $\mathrm{nm}$. Total anthocyanin content (TAC) expressed as cyanidin-3-glucoside was determined using the following formula: 
$\operatorname{TAC}(\mathrm{mg} / \mathrm{L})=\frac{\mathrm{A} \times \mathrm{MW} \times \mathrm{DF}}{\mathrm{E} \times \mathrm{L}} \times 1000$

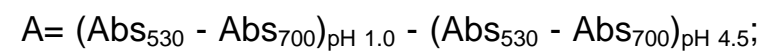
Molecular weight of cyanidin-3-glucoside $(\mathrm{MW})=$ $449.2 \mathrm{~g} / \mathrm{mole}$; Dilution factor $(\mathrm{DF})=7$; Molar absorptivity of cyanidin-3-glucoside $(E)=26900$ $\mathrm{L} / \mathrm{mole} . \mathrm{cm}$; Cell path length $(\mathrm{L})=1 \mathrm{~cm}$.

Total anthocyanin content of anthocyanin extract was also analyzed by $\mathrm{pH}$-differential method, but anthocyanin extract did not need to be extracted. In this case, an aliquot of anthocyanin extract was mixed directly by solvent consisting of $\mathrm{HCl} 2 \mathrm{M}$ : ethanol $70 \%$ with volume ratio of $2 / 3$.

\section{Anthocyanin's destabilization kinetic (Jie et al., 2013)}

Anthocyanin degradation may be due to deglycolisation reaction and is followed by cleavage of anthocyanidin resulted from deglycolisation that will turn into aldehyde and phenolic acid. The kinetics of anthocyanin stability reduction (destabilization) during storage were simplified through the chemical reaction kinetics.

Anthocyanin $\rightarrow$ Degraded anthocyanin

The above reaction can be stated as:

$A \rightarrow C$

The reaction rate can be written as follows:

$\left(-r_{A}\right)=k C_{A}^{n}$

By a batch system reaction approach, the destabilization kinetics can be evaluated as:

$-\frac{d C_{A}}{d t}=k C_{A}{ }^{n}$

By integral method, the equation (5) can be changed to:

$\mathrm{C}_{\mathrm{A} 0}{ }^{1-\mathrm{n}}-\mathrm{C}_{\mathrm{A}}{ }^{1-\mathrm{n}}=(1-\mathrm{n}) \mathrm{kt}$

$\mathrm{C}_{\mathrm{A} 0}$ was initial concentration of anthocyanin, $t$ was reaction time, $C_{A}$ was concentration of anthocyanin at time $t$, and $n$ was reaction order. Especially for the first reaction order $(n=1)$, the equation (5) can be changed to:

$\ln \mathrm{C}_{\mathrm{A}}=\ln \mathrm{C}_{\mathrm{A} 0}-\mathrm{kt}$
To get the value of the reaction rate constant $(k)$ and to find out whether the value of the reaction rate constant can function as the temperature or not, we used the following Arrhenius equation:

$\mathrm{k}=\mathrm{Ae} \mathrm{e}^{-\frac{\mathrm{E}}{\mathrm{RT}}}$

By linearization, equation (8) can be changed to:

$\ln \mathrm{k}=\ln \mathrm{A}-(\mathrm{E} / \mathrm{RT})$

$A=$ frequency factor, $T=$ temperature, $E=$ activation energy.

\section{RESULTS AND DISCUSSION}

\section{Stability profile of encapsulated anthocyanin and anthocyanin extract}

The appearance of encapsulated anthocyanin in wet and dried condition can be seen in Figure 1. It was clear that anthocyanin was encapsulated in a solid matrix. Meanwhile, the stability of encapsulated anthocyanin and also anthocyanin extract are shown at Figure 2. It can be seen at Figure 2 that at various storage temperature, anthocyanin concentration was found to faster decrease in encapsulated anthocyanin compared with anthocyanin extract. It indicated that encapsulated anthocyanin had smaller stability than anthocyanin extract in the high water activity of storage.

Acidity $(\mathrm{pH})$ of system essentially influenced anthocyanin stability. Anthocyanin extract which had higher anthocyanin retention was possible due to the lower $\mathrm{pH}$ of extract i.e. 2.21 compared with encapsulated anthocyanin prepared at $\mathrm{pH}$ of 3.0. The low $\mathrm{pH}$ made the anthocyanin species to be in flavylium cation conformation which had the highest stability. Meanwhile, encapsulated anthocyanin had structure in both flavylium cations and quinoidal bases, which was likely to be the cause of lower stability.

The second factor affecting lower stability of encapsulated anthocyanin was the high water activity $\left(a_{w}\right)$, which was 0.75 . The high water activity which was supported by storage temperatures of 16 , 25,35 , and $45^{\circ} \mathrm{C}$ reduced transition glass temperature $(\mathrm{Tg})$ of the encapsulated anthocyanin. Therefore, encapsulated anthocyanin was shifted to rubbery state. Under these circumstances, the mobility of anthocyanin molecules (reactants) would increase and lead to the increase of anthocyanin degradation through several mechanism, i.e. hydrolysis of chemical, hydrolysis by microbes, the release of sugar moiety, or other possibilities (Garzón and Wrolstad, 2001). 


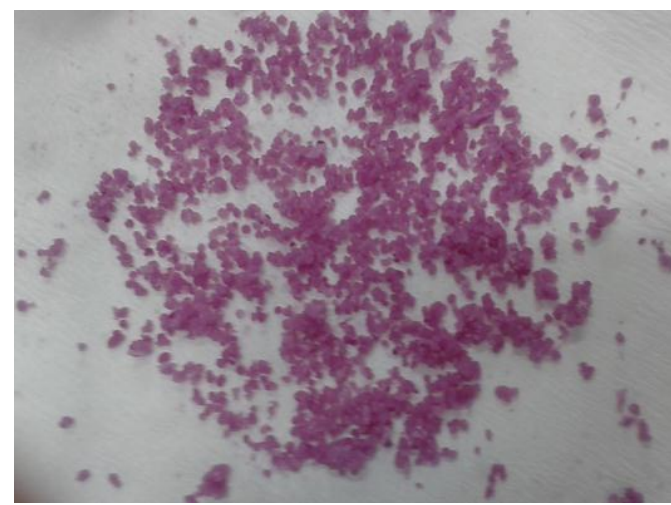

A1

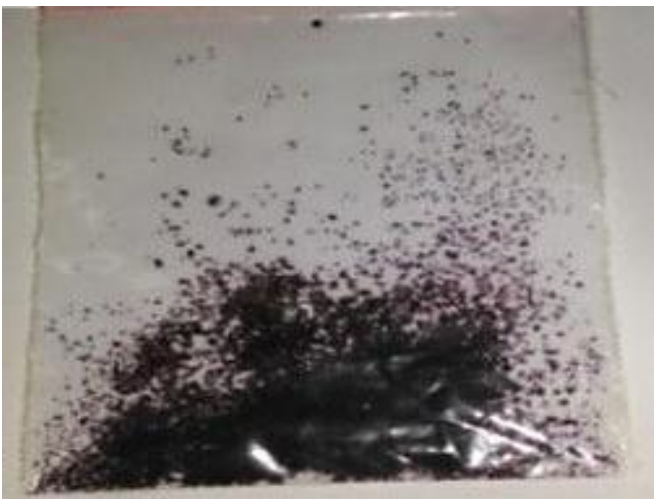

B1

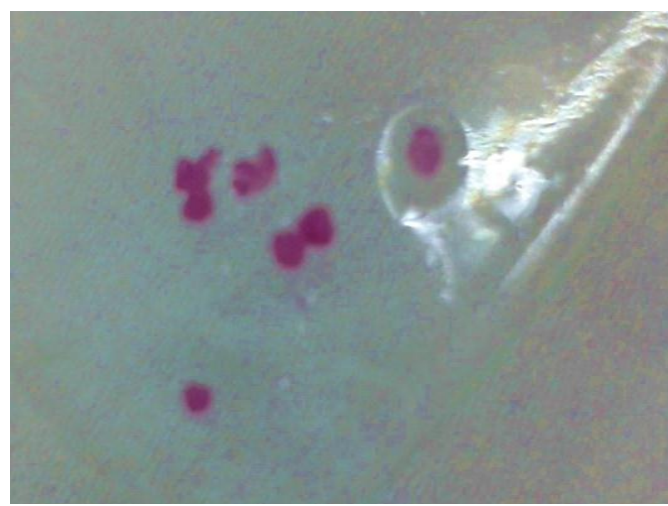

A2

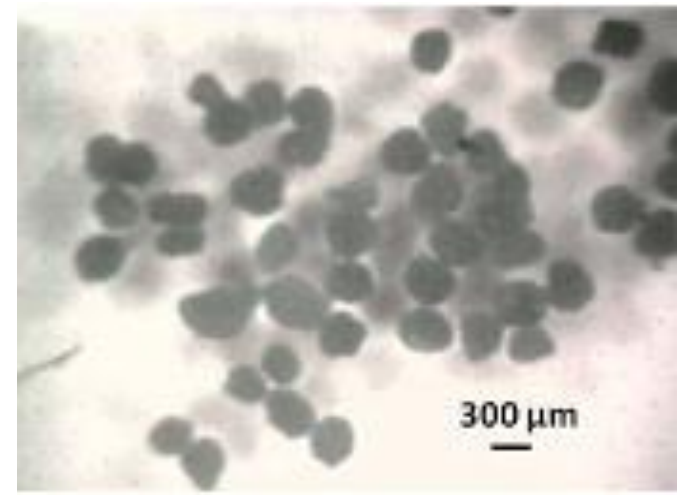

B2

Note: In wet condition (A1); In wet condition with magnification of $4 x$ by digital camera (A2); In dried condition (B1); In dried condition with magnification of $65 x$ by digital microscope (B2)

Figure 1. Appearance of encapsulated anthocyanin

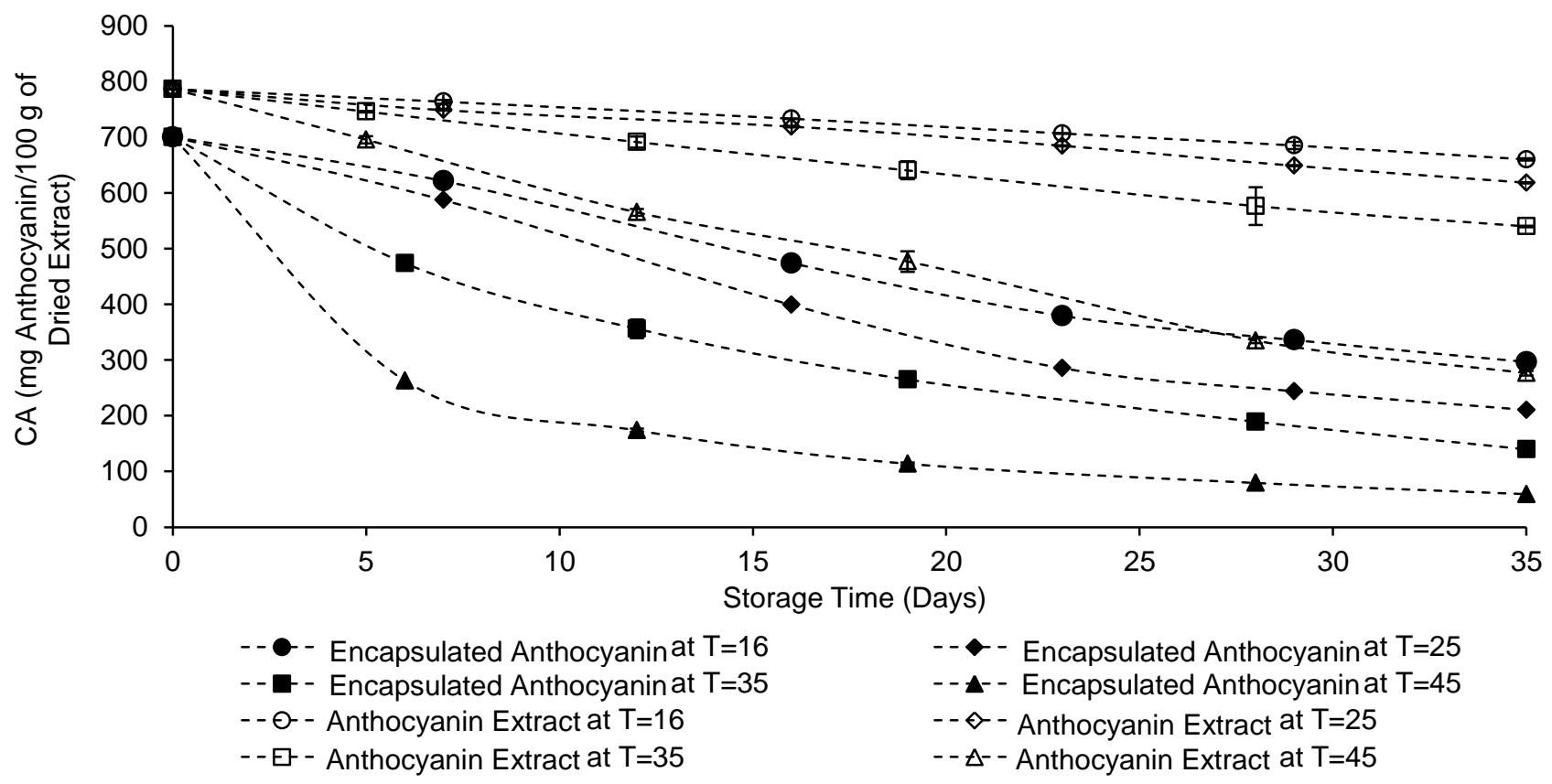

Figure 2. Stability of encapsulated anthocyanin and anthocyanin extract during storage at various temperatures 
The other aspect was the possibility of an interaction between anthocyanin and NaTPP through the formation of a complex between the cation of flavylium and multivalent anion TPP. It was likely that the stability of anthocyanin in complex form differ from anthocyanin in the structure of the flavylium cation.

\section{Kinetic of anthocyanin degradation}

The degradation of kinetic of anthocyanin both in encapsulation system and extract are figured out on Figure 3 and 4 respectively. The figures correlate anthocyanin concentration $\left(C_{A}\right)$ and time in first order kinetic which is stated by $-\ln \left(C_{A} / C_{A 0}\right)$ vs time.
It can be seen that first order reaction gives a good regression coefficient $\left(0,92<r^{2}<0,99\right)$. Therefore, first order $(n=1)$ was available for determining anthocyanin degradation. In the graph of $-\ln \left(C_{A} / C_{A 0}\right)$ vs time, the reaction speed constant value $(\mathrm{k})$ is obtained as a slope of graph. The greater $k$ value was obtained in encapsulated anthocyanin. All the more so, the $\mathrm{k}$ value of encapsulated anthocyanin at $16^{\circ} \mathrm{C}$ was higher than that of anthocyanin extract at $45^{\circ} \mathrm{C}$. Therefore, it is clear that the rate of anthocyanin degradation reaction in encapsulated anthocyanin was greater than that of in anthocyanin extract stored in water activity of 0.75 .

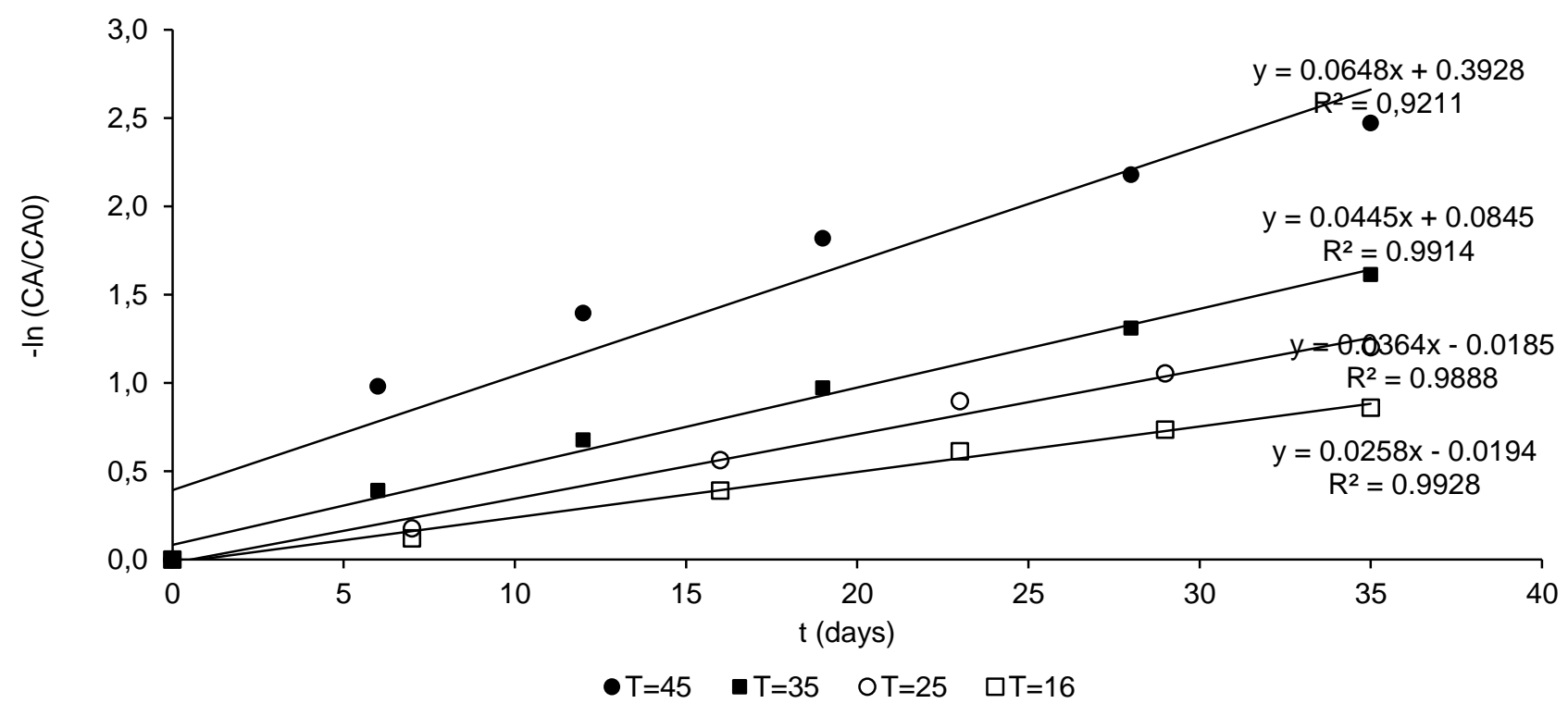

Figure 3. The kinetics of encapsulated anthocyanin degradation

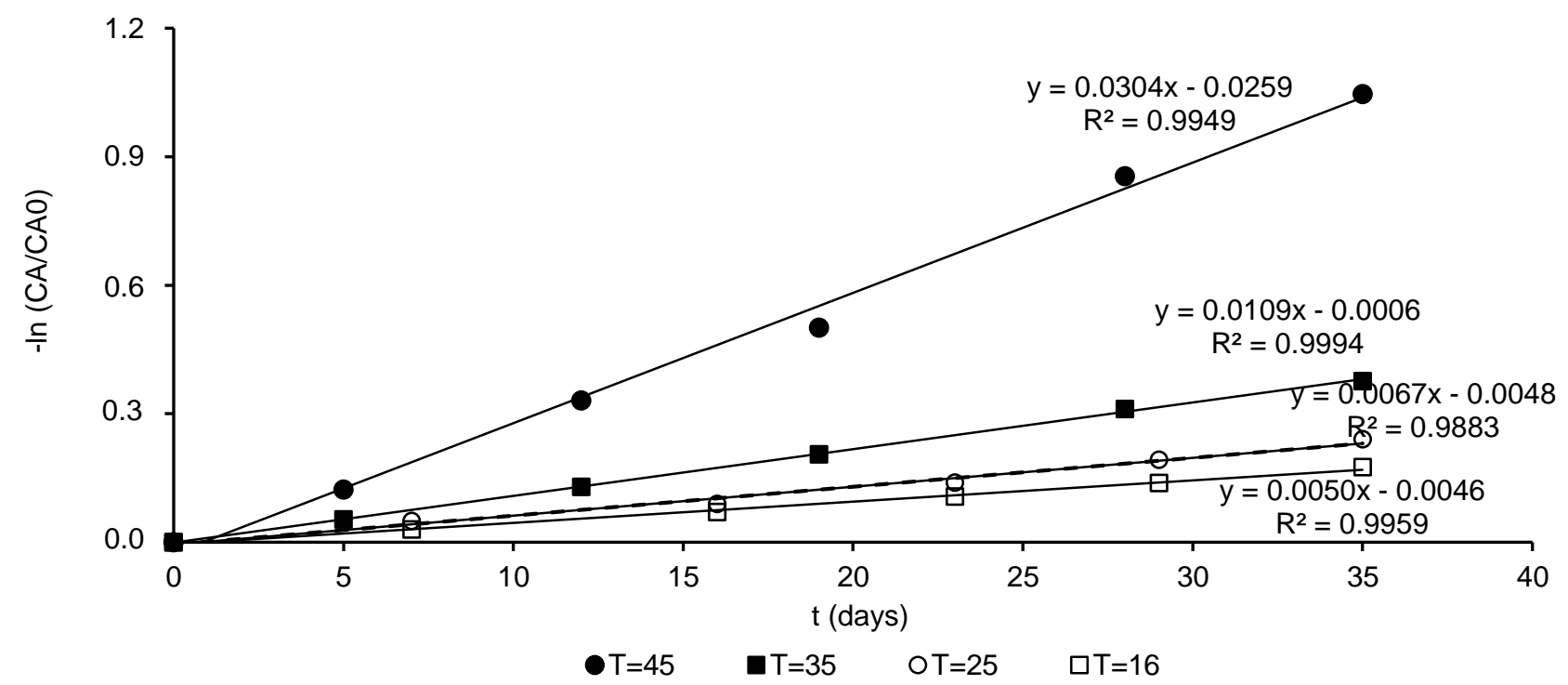

Figure 4. The kinetics of anthocyanin extract degradation 
The greater $k$ value of encapsulated anthocyanin might be due to $\mathrm{pH}$ factor in which encapsulated anthocyanin had higher $\mathrm{pH}$ than anthocyanin extract. It was agreed with the research of Oancea and Draghici (2013) that the increase of $\mathrm{pH}$ would improve anthocyanin degradation of kinetic constant value (k). Loypimai et al. (2016) also obtained that $\mathrm{k}$ value would be higher with increasing temperature and $\mathrm{pH}$. The other factor was high water activity that allows the presence of encapsulated anthocyanin in rubbery state as had been explained before.

Anthocyanin degradation in encapsulated anthocyanin and anthocyanin extracts following first order kinetic were consistent with other studies. Jie et al. (2013) observed anthocyanin stability in purple sweet potato solution. Based on the study, it was found that anthocyanin stability followed first order kinetic. Nayak et al. (2011) obtained anthocyanin degradation in purple-fleshed potato following first order reaction kinetics model. Figure 3 and 4 indicate that the higher the temperature, the greater the rate of anthocyanin degradation. The reaction speed constant (k) increased with increasing temperature for encapsulated anthocyanin and anthocyanin extract. This means that $\mathrm{k}$ is a function of temperature (T) as is figured out at Figure 5.

The kinetic parameters of anthocyanin degradation in encapsulated and extracts can be seen at Table 1. The activation energy of anthocyanin degradation in encapsulated anthocyanin was 23.33 $\mathrm{kJ} /$ mole and the activation energy of anthocyanin degradation in the extract was $46.70 \mathrm{~kJ} / \mathrm{mole}$ still in the same range as other studies. Jie et al. (2013) obtained that activation energy of anthocyanin degradation for purple sweet potato juice with $\mathrm{pH}$ of 2-6 was $66.5-111.57 \mathrm{~kJ} / \mathrm{mole}$. Chen et al. (2019) got almost the same results, namely the activation energy for purple sweet potato extract degradation with a pH of 3 that was $59.55 \mathrm{~kJ} /$ mole.

The activation energy in anthocyanin degradation of encapsulated anthocyanin was smaller than that of the anthocyanin extract. This indicates that only less energy was needed by encapsulated anthocyanin to initiate anthocyanin degradation. Meanwhile, the activation energy of anthocyanin extract obtained was greater, thus kinetic of anthocyanin degradation of extract was more sensitive to temperature compared with encapsulated anthocyanin. Another parameter that can be reviewed was the half-life $\left(t_{1 / 2}\right)$, which is the time needed for anthocyanin degradation to occur by $50 \%$. It can be seen from Table 1 that half-life of encapsulated anthocyanin was smaller than anthocyanin extract by a factor of 3 to 6 in the temperature range of 16$45^{\circ} \mathrm{C}$. This convinces that the rate of anthocyanin degradation in encapsulated anthocyanin was greater than that in anthocyanin extract.

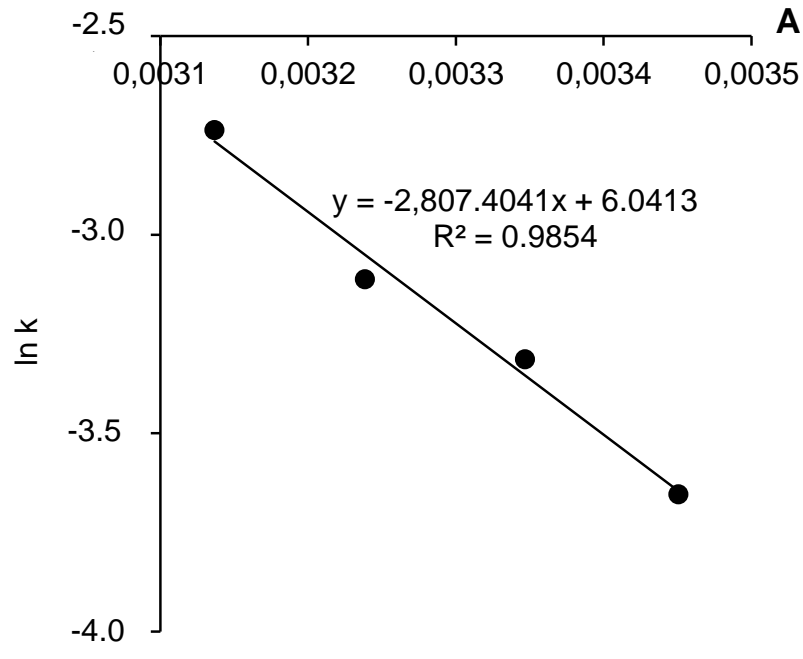

$1 / \mathrm{T}(\mathrm{K}-1)$

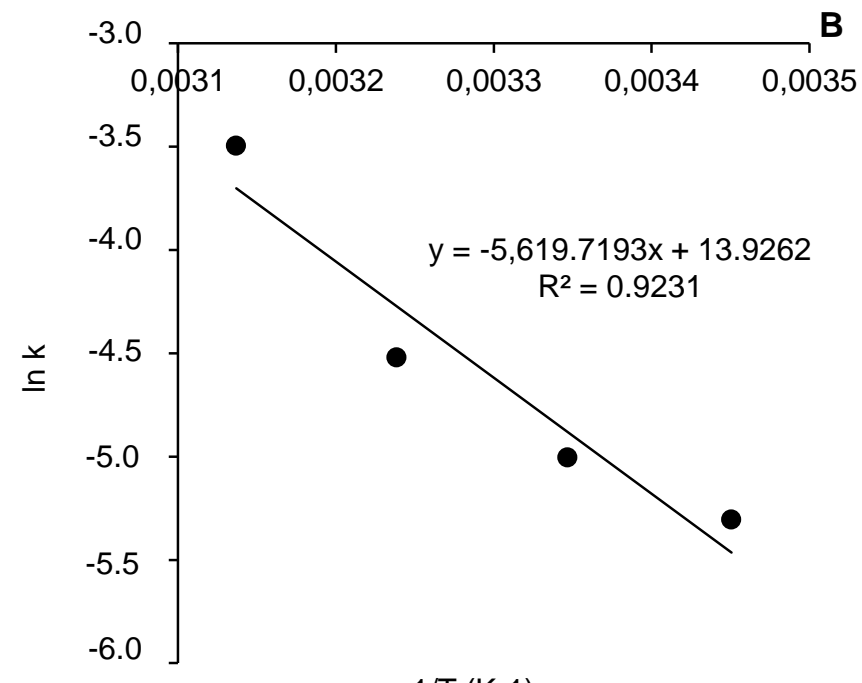

$1 / \mathrm{T}(\mathrm{K}-1)$

Figure 5. The relationship of $k$ and $T$ at encapsulated anthocyanin (A) and anthocyanin extract (B) 
Table 1. The kinetic parameters of anthocyanin degradation in encapsulated anthocyanin and anthocyanin extract

\begin{tabular}{|c|c|c|c|c|c|}
\hline $\begin{array}{l}\text { Storage Condition } \\
\text { Temperature }\left({ }^{\circ} \mathrm{C}\right)\end{array}$ & $\begin{array}{c}\mathrm{k} \\
\text { (1/day) }\end{array}$ & $\begin{array}{c}\mathrm{A} \\
\text { (Frequency Factor) }\end{array}$ & $\begin{array}{c}\mathrm{Ea} \\
(\mathrm{kJ} / \mathrm{mole})\end{array}$ & $\mathrm{R}^{2}$ & $\begin{array}{c}\mathrm{t}_{1 / 2} \\
\text { (Days) }\end{array}$ \\
\hline \multicolumn{6}{|c|}{ Encapsulated Anthocyanin } \\
\hline 16 & 0.0259 & 420.44 & 23.33 & 0.9854 & 26.54 \\
\hline 25 & 0.0364 & 420.44 & 23.33 & 0.9854 & 19.82 \\
\hline 35 & 0.0445 & 420.44 & 23.33 & 0.9854 & 14.62 \\
\hline 45 & 0.0648 & 420.44 & 23.33 & 0.9854 & 10.99 \\
\hline \multicolumn{6}{|l|}{ Anthocyanin Extract } \\
\hline 16 & 0.0050 & $1.12 \times 10^{6}$ & 46.70 & 0.9231 & 163.86 \\
\hline 25 & 0.0067 & $1.12 \times 10^{6}$ & 46.70 & 0.9231 & 91.37 \\
\hline 35 & 0.0109 & $1.12 \times 10^{6}$ & 46.70 & 0.9231 & 49.69 \\
\hline 45 & 0.0304 & $1.12 \times 10^{6}$ & 46.70 & 0.9231 & 28.08 \\
\hline
\end{tabular}

\section{CONCLUSION}

Stability of encapsulated anthocyanin was investigated regarding with lower stability of anthocyanin at high water activity and high temperature. The testing stability was conducted at water activity of 0.75 and various temperature at $16,25,35$, and $45^{\circ} \mathrm{C}$. The kinetic parameters including kinetic constant $(k)$, reaction order, and half-life $\left(t_{1 / 2}\right)$ were also studied. For comparison, anthocyanin extract was also tested for its stability using the same condition. This study revealed that encapsulated anthocyanin had lower stability than anthocyanin extract. The result was proven by higher kinetic constant and lower half-life. The lower stability of encapsulated anthocyanin had been induced by higher $\mathrm{pH}$ of encapsulated anthocyanin than anthocyanin extract. It was conclusive that the $\mathrm{pH}$ affected the amount of flavylium cation conformation. In addition, high water activity also caused lower stability by reducing glass transition temperature $(\mathrm{Tg})$ by which encapsulated anthocyanin was shifted to rubbery state. Anthocyanin degradation in encapsulated anthocyanin and anthocyanin extract followed first order kinetic. The degradation kinetic constant of encapsulated anthocyanin was stated as $k=420.44 \exp (-23.33 / R T)$ and in anthocyanin extract was stated as $k=1.12 \times 10^{6}$ $\exp (-46.70 / R T)$. Based on the stability test, the application of encapsulated anthocyanin was not suitable for wet-type food product. Further study about stability of the encapsulated anthocyanin in lower water activity is essential to do as a way to investigate the application of encapsulated anthocyanin in dry-type food product.

\section{ACKNOWLEDGEMENT}

This research was supported by Fellowship of Ministry of Research, Technology and Higher Education of the Republic of Indonesia 2014/2016.
Alpizar-Reyes E, Carrillo-Navas H, Romero-Romero R, Varela-Guerrero V, Alvarez-Ramírez J, Pérez-Alonso C. 2017. Thermodynamic sorption properties and glass transition temperature of tamarind seed mucilage (Tamarindus indica L.). Food Bioprod Process 101: 166-176. DOI: 10.1016/j.fbp.2016.11.006.

Askar KA, Alsawad ZH, Khalaf MN. 2015. Evaluation of the $\mathrm{pH}$ and thermal stabilities of rosella anthocyanin extracts under solar light. BeniSuef University J Basic Appl Sci 4: 262-268. DOI: 10.1016/j.bjbas.2015.06.001.

Bueno JM, Ramos-Escudero F, Saez-Plaza $P$, Munoz AM, Navas MJ, Asuero AG. 2012. Analysis and antioxidant capacity of anthocyanin pigments. part 1: general considerations concerning polyphenols and flavonoids. Crit Rev Anal Chem 42: 102-125. DOI: 10.1080/104083 47.2011.632312.

Chen C-C, Lin C, Chen M-H, Chiang P-Y. 2019. Stability and quality of anthocyanin in purple sweet potato extracts. Foods 8: 393 . DOI: 10.3390/foods8090393.

Diniyah N, Susanto T, Nisa FC. 2010. Uji stabilitas antosianin pada kulit terung. Agro-Techno 1: 575-579.

Faria A, Fernandes I, Mateus N, Calhau C. 2013. Bioavailability of anthocyanins. Nat Prod 2013: 2465-2487. DOI: 10.1007/978-3-642-22144-6 75.

Garzón GA, Wrolstad R. 2001. The Stability of pelargonidin-based anthocyanis at varying water activity. Food Chem 75: 185-196. DOI: 10. 1016/S0308-8146(01)00196-0.

Giusti M, Wrolstad RE. 2001. Characterization and measurement of anthocyanins by uv-visible spectroscopy. Curr Protocols in Food Anal Chem 2001: 1-13. DOI: 10.1002/0471142913. faf0102s00. 
Hou F, Zhang R, Zhang M, Su D, Wei Z, Deng Y, Zhang Y, Chi J, Tang X. 2013. Hepatoprotective and antioxidant activity of anthocyanins in black rice bran on carbon tetrachlorideinduced liver injury in mice. J Funct Foods 5: 1705-1713. DOI: 10.1016/j.jff.2013.07.015.

Jie L, Xiao-ding L, Yun Z, Zheng-dong Z, Zhi-ya Q, Meng L, Shao-hua Z, Shuo L, Meng W, Lu Q. 2013. Identification and thermal stability of purple-fleshed sweet potato anthocyanins in aqueous solutions with various $\mathrm{pH}$ values and fruit juices. Food Chem 136: 1429-1434. DOI: 10.1016/j.foodchem.2012.09.054.

Justino GC. 2017. Flavonoids - From Biosynthesis to Human Health. 207. Intech, Zagreb, Croatia. DOI: $10.5772 / 65575$.

Kanokpanont S, Yamdech R, Aramwit P. 2018. Stability enhancement of mulberry-extracted anthocyanin using alginate/chitosan microencapsulation for food supplement application. Artif Cell Nanomed B 46: 773-782. DOI: 10. 1080/21691401.2017.1339050.

Khoo HE, Azlan A, Tang ST, Lim SM. 2017. Anthocyanidins and anthocyanins: colored pigments as food, pharmaceutical ingredients, and the potential health benefits. Food Nutr Res 61: 136-177. DOI: 10.1080/16546628.2017.13617 79.

Laila U, Rocmadi, Pudjiraharti S. 2019. Microencapsulation of purple-fleshed sweet potato anthocyanins with chitosan-sodium tripolyphosphate by using emulsification-crosslinking technique. J Math Fund Sci 5: 29-46. DOI: 10.5614/ j.math.fund.sci.2019.51.1.3.

Loypimai $\mathrm{P}$, Moongngarm $\mathrm{A}$, and Chottanom $\mathrm{P}$. 2016. Thermal and ph degradation kinetics of anthocyanins in natural food colorant prepared from black rice bran. J Food Sci Technol 53: 461-470. DOI: 10.1007/s13197-015-2002-1.

Martynenko A, Chen Y. 2016. Degradation kinetics of total anthocyanins and formation of polymeric color in blueberry hydrothermodynamic (HTD) processing. J Food Eng 171: 44-51. DOI: 10. 1016/j.jfoodeng.2015.10.008.
Nayak B, Berrios JDJ, Powers JR, Tang J. 2011. Thermal degradation of anthocyanins from purple potato (cv. purple majesty) and impact on antioxidant capacity. J Agric Food Chem 59: 11040-11049. DOI: 10.1021/jf201923a.

Oancea S, Draghici O. 2013. pH and thermal stability of anthocyanin-based optimised extracts of romanian red onion cultivars. Czech $\mathrm{J}$ Food Sci 3: 283-291. DOI: 10.17221/302/2012CJFS.

Parisi OI, Puoci F, Restuccia D. 2014. Polyphenols and their formulations: different strategies to overcome the drawbacks associated with their poor stability and bioavailability. Polyphenols in Hum Health and Dis 1: 29-45. DOI: 10.1016/ B978-0-12-398456-2.00004-9.

Patras A, Brunton NP, O'Donnell C, Tiwari BK. 2010. Effect of thermal processing on anthocyanin stability in foods: mechanisms and kinetics of degradation. Trends Foods Sci Technol 21: 3-11. DOI: 10.1016/j.tifs.2009.07. 004.

Slade L, Levine H. 1991. Beyond water activity: recent advances based on an alternative approach to the assessment of food quality and safety. Crit Rev Food Sci Nutr 30:115-360. DOI: 10.1080/10408399109527543.

Sun J, Bai W, Zhang Y, Liao X, Hu X. 2011. Identification of degradation pathways and products of cyanidin-3-sophoroside exposed to pulsed electric field. Food Chem 126: 12031210. DOI: 10.1016/j.foodchem.2010.12.002.

Turumtay EA, Turumtay H, Demir A, Selvi EK, Yazici E, Sandallı C, Yazıcı ZA. 2015. Anthocyanins profiling of Thymus praecox opiz subsp. caucasicus var. caucasicus. Ind Crops Prod 77: 748-753. DOI: 10.1016/j.indcrop.201.062.

Whitson J, McDougall GJ, Ross HA, Lund VA, Hamilton CA, Dominiczak AF, Stewart D. 2010. Bioactive Berry Components: Potential Modulators of Health Benefits. Funct Plants Sci Biotechnol 4: 34-39. 